Discussion Paper No. 07-039

\title{
Implications of
}

Network Convergence on Local Access Regulation in the U.S. and the EU

Margit A. Vanberg

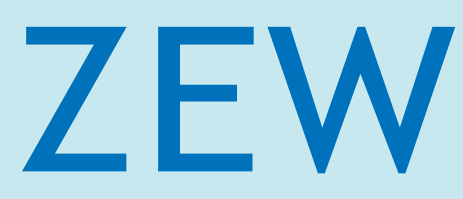

Zentrum für Europäische Wirtschaftsforschung $\mathrm{GmbH}$ Centre for European Economic Research 
Discussion Paper No. 07-039

\title{
Implications of \\ Network Convergence on Local Access Regulation in the U.S. and the EU
}

\author{
Margit A. Vanberg
}

Download this ZEW Discussion Paper from our ftp server:

ftp://ftp.zew.de/pub/zew-docs/dp/dp07039.pdf

Dank gilt der Landesstiftung Baden-Württemberg für die finanzielle Unterstützung der Forschungsarbeit.

Financial support by the Landesstiftung Baden-Württemberg foundation is gratefully acknowledged.

Die Discussion Papers dienen einer möglichst schnellen Verbreitung von neueren Forschungsarbeiten des ZEW. Die Beiträge liegen in alleiniger Verantwortung der Autoren und stellen nicht notwendigerweise die Meinung des ZEW dar.

Discussion Papers are intended to make results of ZEW research promptly available to other economists in order to encourage discussion and suggestions for revisions. The authors are solely responsible for the contents which do not necessarily represent the opinion of the ZEW. 


\section{Non-Technical Summary}

This paper provides an overview of telecommunications regulation in the U.S. and in Europe. For each region the history of telecommunications regulations as well as the current regulatory regime is portrayed. The focus of this overview is on the question of how unbundling regulations in the local access market have evolved in parallel to the convergence of telecommunications with Internet and broadcasting services. The criteria used by the regulatory authorities to identify those network elements which incumbents are required to offer to competitors at regulated rates are compared to the criteria provided by the "essential facilities doctrine", a concept used in antitrust law.

In the U.S., liberalization of local telecommunications services was introduced in 1996 and was at first accelerated by intensive unbundling regulations. Network convergence has since had a clear impact on U.S. unbundling policy. Beginning in 2003, U.S. unbundling legislation has been limited to the provision of narrowband access to the copper local loop. For competition in broadband access services, the U.S. regulatory regime relies mainly on infrastructure-platform competition from Cable-TV networks and high-speed wireless technologies. High-capacity local loops need only be unbundled at wire centers located in a region with very few business customers.

In Europe full liberalization of telecommunications services provision was introduced in 1998. In answer to network convergence, the new EU Regulatory Framework for electronic communications of March 2002 extends the scope of regulation to other electronic communications platforms. The analysis finds a severe tendency to overregulation in Europe. Several of the wholesale markets regulated are, for instance, substitutes for one another.

The analysis concludes that the U.S. trend to deregulation has gone too far with respect to some broadband access markets. The importance of competitive broadband access is increasing with the advent of Next Generation Network services. For those geographic markets in which no infrastructure-platform competition exists or is likely to develop, the FCC should use the instruments provided by the Telecommunications Act of 1996 to regulate unbundled access for broadband services. In Europe, in contrast, the possibilities provided by the framework legislation, to limit current overregulation, should be taken advantage of. The current review of the 2002 Regulatory Framework provides the Commission with an opportunity to severely reduce its list of markets recommended for ex-ante regulation. 


\title{
Implications of Network Convergence on Local Access Regulation in the U.S. and the EU
}

\author{
MARGIT A. VANBERG* \\ Centre for Economic Research (ZEW), Mannheim
}

June 2007

\begin{abstract}
This paper provides an overview of telecommunications regulation in the U.S. and in Europe. For each region the history of telecommunications regulations as well as the current regulatory regime is portrayed. The focus of this overview is on the question of how unbundling regulations in the local access market have evolved in parallel to the convergence of telecommunications with Internet and broadcasting services. The criteria used by the regulatory authorities to identify those network elements which incumbents are required to offer to competitors at regulated rates are compared to the criteria provided by the "essential facilities doctrine", a concept used in antitrust law. The analysis concludes that U.S. deregulation has gone too far with respect to some broadband access markets while in Europe, a severe tendency to overregulation is observed.
\end{abstract}

Keywords: network convergence; unbundling regulation;

JEL classification: L15; L43

ZEW, P.O. Box 1034 43, D-68034 Mannheim. Tel.: +49 69621 1235-351. E-mail: vanberg@zew.de.

I thank Irene Bertschek, Franziska Birke and Günter Knieps for their comments and suggestions.

Financial support by the Landesstiftung Baden-Württemberg foundation is gratefully acknowledged. 


\section{Introduction}

In telecommunications networks, sector-specific regulation of the physical network layer has a long tradition. Originally, telecommunications regulation was motivated by the objective to increase competition in voice telecommunications services. The trend to the convergence of telecommunications, media and Internet services, and especially the resulting ISP demand for broadband access to the local telecommunications infrastructure, has recently left a strong imprint on telecommunications policy.

This paper provides an overview of telecommunications regulation in the U.S., as the "birthcountry" of the Internet (Section 2), as well as of telecommunications regulation in Europe (Section 3). For each region the history of telecommunications regulations as well as the current regulatory regime is portrayed. The focus of this overview is on the question of how unbundling regulations in the local access market have evolved in parallel to the convergence of telecommunications with Internet and broadcasting services. The paper concludes with a summary and outlook in Section 4.

\section{The regulatory framework for the telecommunications industry in the U.S. ${ }^{1}$}

\subsection{History of Telecommunication Regulation in the U.S.}

The legal framework for telecommunications regulation in the United States builds on the Communications Act of $1934 .^{2}$ At the time of its legislation, telecommunications services were considered to be natural monopolies and the Communications Act established legal entry barriers into telecommunications services. The Federal Communications Commission (FCC), which was created to oversee the monopoly provision of telecommunications services by AT\&T, was given the power to allow market entry, should this be considered in the interest of the general public. ${ }^{3}$

\footnotetext{
For a detailed account see Speta (2004).

48 Stat. 1064 (1934) (codified as amended at 47 U.S.C. $\$ \S 151$ et seq.) available at http://www.fcc.gov/Reports/1934new.pdf.

47 U.S.C. § 214.
} 
The U.S. began liberalizing its telecommunications markets well before any European country. In 1959 partial market opening was initiated by an FCC decision to allow market entry into specialized private line communications services. Competitors used technological innovations in microwave transmission technology to offer point to point telecommunications services to corporate customers. Further technological developments, also in satellite technology, added to the competitive pressure emanating from new entrants. In 1980 the FCC allowed market entry into interstate public switched telecommunications services. ${ }^{4}$ The prospective danger that AT\&T could abuse its monopoly power in local telecommunications to finance predatory prices in long-distance communications led to the divestiture of AT\&T. In 1984 AT\&T was split into a long-distance venture and seven regional holding companies, each in charge of traffic transmission within a local access and transport area (LATA). ${ }^{5}$ The regional Bell companies were obliged to offer nondiscriminatory access to their intra-LATA network to all providers of long-distance services.

In parallel to the developments in telecommunications technology which facilitated telecommunications liberalization, computer processing became available to the general public. Already in the 1960s, the Federal Communications Commission saw a need to investigate how computer processing should be treated in differentiation to telecommunications services. Would existing regulatory measures need to be extended to the data processing market, which showed similarities to traditional telecommunications services? The FCC conducted such investigations in 1971, 1980 and 1986. In the respective Computer Inquiries I, II and III the FCC came to the conclusion that data processing, and the communication services provided over data processing equipment, are competitive. The Commission thereafter differentiated between traditional telecommunications services, regulated under the Communications Act and "enhanced services”, defined as “...services offered over common carrier transmission facilities used in interstate communications, which employ computer processing applications that act on the format, content, code, protocol, or similar aspects of the subscriber's transmitted information; provide the subscriber additional, different or restructured information; or involve subscriber interaction with stored information” (Oxman, 1999: 10-11) ${ }^{6}$. The emerging Internet applications were categorized to be enhanced services. The FCC explicitly determined that enhanced services were not to be subjected to industry-specific regulations.

4 See Knieps (1985: 105-106).

5 For a more detailed account of the AT\&T breakup see Speta (2004: 23ff). 
Out of the fear that providers of traditional telecommunications services could be able to foreclose the market for enhanced services by cross-subsidizing own information services operations, Computer Inquiry II placed limitations on common carriers, should they wish to offer enhanced services to the public. The FCC determined that providers of transmission services may offer enhanced services only through a structurally separate affiliate. Computer Inquiry III introduced an alternative by which a company offering transmission services can comply with the structural separation standard. A provider of transmission services would be allowed to offer enhanced services, provided that it would open its network architecture to competitors and keep separate accounts for its activities in enhanced services (Oxman, 1999: 11). The non-structural separation standard inherent in this Open Network Architecture (ONA) legislation of the Computer Inquiries can be seen as a forerunner of unbundling regulation.

In 1990, before most European Countries even began the liberalization process, the FCC began phasing out some of its telecommunications regulations. The FCC found that particular longdistance markets had become sufficiently competitive to no longer warrant rate regulation. In 1995 AT\&T was declared to no longer be dominant in the market for interstate interexchange traffic and all of AT\&T’s domestic long-distance services were no longer subjected to price cap regulation. In 1996 rate regulation of international calls was eliminated. ${ }^{7}$

In 1996 the U.S. Congress passed the Telecommunications Act of $1996^{8}$. This Act has been the most substantial amendment to the Communications Act of 1934. It introduced full competition into all telecommunications markets by abolishing the remaining legal entry barriers into local telecommunications services. ${ }^{9}$ The Act places on all telecommunications services providers the duty to interconnect "...directly or indirectly with the facilities and equipment of other telecommunications carriers”10. Facilities based entrants into local telecommunications were

6 In U.S. legislation, the term common carriers refers to providers of transportation services to the public, be it traditional transportation services such as bus or rail transport, or data transportation via the telecommunications network.

7 See Marcus (2002:21-22).

8 Telecommunications Act of 1996, Pub. LA. No. 104-104, 110 Stat. 56 (1996) available at http://www.fcc.gov/Reports/tcom1996.pdf.

9 Since the EU member countries fully liberalized their telecommunications markets in 1998, full liberalization of telecommunications was implemented almost at the same time in these two regions (see section 9.2).

10 Section 251(a)(1) of the 1996 Act. 
therefore guaranteed interconnection with incumbent carriers. Incumbents were further obliged to offer interconnection on cost-based, non-discriminatory terms.

To further support the evolvement of competition in local telecommunications services the 1996 Act grants the FCC two regulatory instruments that go beyond access by interconnection (Hausman and Sidak, 2000: 432). First, the incumbent local exchange carriers (ILECs) can be compelled to offer their local services on a wholesale basis for resale purposes of competitors. Second, and more invasive from the point of view of the incumbent, the ILECs can be obligated to unbundle network elements of their local infrastructure and to offer these to competing local exchange carriers (CLECs) whenever:

“(A) access to such network elements as are proprietary in nature is necessary; and

(B) the failure to provide access to such network elements would impair the ability of the telecommunications carrier seeking access to provide the services that it seeks to offer." 11

These prerequisites for unbundling together have become known as the "necessary" and "impair" requirements (Hausman and Sidak, 2000: 433).

The FCC implemented the unbundling provisions of the Telecommunications Act in its Local Competition Order (FCC, 1996). In this order the FCC instructed all ILECs to unbundle seven network elements of the local market ${ }^{12}$. The criterion the FCC applied for identifying these network elements as satisfying the "necessary" and "impair" standard, was that a new entrant would not be able to offer telecommunications services at same costs as the incumbent without access to these network elements (Bauer, 2005: 64). The regulated rates at which the incumbents would be required to offer the network elements were based on forward looking long run incremental costs ${ }^{13}$.

11 Section 251(d)(2) of the 1996 Act. This definition in the 1996 Act is in short often referred to as the "necessary and impair standard".

12 These seven elements were: (1) local loops, (2) network interface devices, (3) local and tandem switching, (4) interoffice transmission facilities, (5) signaling networks and call-related databases, (6) operations support systems and (7) operator services and directory assistance.

13 For more detail on the FCC's interpretation of the "necessary" and "impair" standard see Hausman and Sidak (2000: 434-435). 
The FCC's interpretation of the Telecommunication Act led to wider and more comprehensive unbundling requirements than were, for instance, instated in the European Countries which fully liberalized their telecommunications markets at almost the same time. In the U.S. all of the network elements needed to provide circuit-switched local telecommunications services were covered by the unbundling obligations. Furthermore, ILECs were even required to provide the unbundled network elements in such a way as to allow competitors to use these in combination without having to invest into any network infrastructure of their own or even having to send out technicians to coordinate the combined use (Nuechterlein and Weiser, 2005: 96). This combined UNE offer, also called the UNE platform service (UNE-P), therefore technically corresponds to a resale offer of local telecommunications services. Because of the different regulated prices for UNE offers (TELRIC ${ }^{14}$ ) and for Resale offers (Retail minus avoided costs for marketing, invoicing and billing) UNE-P is essentially a resale offer at considerably lower costs to competitors. UNE-P consequently proved to be very popular with new entrants. Among ILECs and also among many academic commentators of the regulation process UNE-P regulation was highly contested (See Hausman and Sidak, 2005: 177, Vogelsang, 2005 and Bauer, 2005).

\subsection{The present Regulatory Framework}

There were several appeals before the courts against the FCC interpretation of the 1996 Telecommunications Act. The following focuses only on the ultimate results of a long legal battle over the proper implementation of the legislation laid down in the 1996 Act. $^{15}$ A Supreme Court decision in 1999 and a D.C. Circuit Court of Appeals decision in 2003 found that the FCC had to reconsider its unbundling requirements and to significantly reduce the scope of its unbundling regulation. In particular, the FCC was called upon to take more account of infrastructure-platform competition from, for instance, Cable-TV operators or operators of wireless access technologies. Regulation was not to take away investment incentives for facilities-based entry, especially in the newly emerging broadband access markets. Furthermore, the FCC was called upon to observe differences in "particular markets and particular customer classes” instead of applying regulations on a nation-wide basis (FCC 2004, 7ff).

\footnotetext{
14 TELRIC stands for Total Element Long Run Incremental Costs. This is a forward-looking cost accounting approach, which assumes that the network to be unbundled was build in a greenfield situation and is efficient for the purpose to which it is applied.

15 Bauer (2005) provides a more detailed overview of the process.
} 
In response to the court decisions, the FCC revised its approach for locating those network elements which were to be unbundled from the criterion whether unbundling is technologically possible and associated with lower costs for competitors to focusing on whether a "reasonably efficient” competitor cannot economically duplicate the network element in question due to structural barriers to entry in the market. This criterion is closer to the definition of "essential facilities" as used in general competition law. ${ }^{16}$ The FCC now defines structural entry barriers as characterized by (1) economies of scale; (2) sunk costs; (3) first-mover advantages; (4) absolute cost advantages; and (5) barriers within the control of the incumbent (FCC, 2005: 4 and 8). The essential facilities doctrine is more specific in that it requires a competitor's inability to practically or reasonably duplicate the facility. The application of the essential facilities doctrine therefore presupposes a natural monopoly in the relevant market. In the FCC definition of structural entry barriers the natural monopoly requirement is not as clearly defined. The FCC is therefore left with room for wider interpretation of the unbundling requirements than the essential facilities doctrine would extend. ${ }^{17}$

Using the new criteria, the FCC abolished much of the previous unbundling regulations and especially those obligations which focused on the broadband access network. ${ }^{18}$ For those network elements no longer regulated, competitive providers must now either pay unregulated rates, should the incumbent continue to offer access to these network elements, or they must build out their own network infrastructure (or exit the market).

16 The federal courts first applied the essential facilities doctrine in 1983. In the case MCI Communications Corp. vs. American Telephone \& Telegraph Co. the Seventh Circuit defined a four-part test by which the plaintiff needs to show "(1) control of the essential facility by a monopolist; (2) a competitor's inability practically or reasonably to duplicate the essential facility; (3) the denial of the use of the facility to a competitor; and (4) the feasibility of providing the facility." (Hausman and Sidak, 2000: 467).

17

There exists a concept which defines a class of cases which can be identified ex-ante as fulfilling the criteria of the essential facilities doctrine. This bottleneck theory (Knieps, 1997) is specialized in the localization of market power in network industries. It argues that monopolistic bottlenecks, which combine natural monopoly characteristics (due to economies of scale and scope in the relevant range of output) with substantial sunk costs lend network-specific market power to the incumbent firm. A monopolistic bottleneck hinders potential competitors from effectively disciplining active firms, because the incumbent firm has less decision-relevant costs than potential competitors due to the sunk costs involved in supplying the monopolistic bottleneck. The difference in the bottleneck theory and the essential facilities doctrine is not their definition of what constitutes an essential facility or a monopolistic bottleneck but rather that an essential facility is a concept used in the context of general competition policy, which takes effect only ex-post and is applied on a case-by-case basis, whereas a monopolistic bottleneck is a concept developed for the use in sector-specific regulation because it defines a class of cases which can be identified ex-ante and regulated ex-ante (Knieps, 2006: 54).

18 The revisions of the unbundling rules are in the Triennial Review Order of 2003 (FCC, 2003), in the Order on Reconsideration of 2004 (FCC, 2004) and in the Triennial Review Remand Order of 2005 (FCC, 2005). 
Among the obligations which were removed are line-sharing obligations (FCC, 2003). It was further determined that high-capacity interoffice transport routes and high-capacity local loops need only be unbundled under particular local circumstances (whenever the number of businesslines between or to wire centers and the number of fiber-based collocators at a wire center fall under a given threshold, thereby indicating that revenue opportunities in this particular geographic area may not justify facilities duplication) (FCC, 2004: 43-44 and 82-83). Furthermore, with respect to new generation networks the investments of ILECs into fiber to the home (FTTH) and fiber to the curb (FTTC) projects were explicitly exempted from unbundling requirements (FCC, 2003 and 2004). The FCC only clarified that “...where a FTTH loop is deployed in overbuild, or "brownfield" situations, [...] LECs must either provide unbundled access to a $64 \mathrm{kbps}$ transmission path over the fiber loop or unbundled access to a spare copper loop.” (FCC, 2004:3). Finally, UNE-P regulation was also abolished, and with it all requirements to offer local circuit switching at regulated rates (FCC, 2004: 109ff).

In an order released in September $2005^{19}$ the FCC further eliminated all open access requirements on wireline broadband access providers established by the Computer Inquiries. Wireline broadband access providers had been obliged to make available transmission capacity to unaffiliated ISPs. The FCC determined that DSL services to be information services, and therefore relieved wireline telephone operators of the unbundling obligations for wholesale broadband access. $^{20}$ The reclassification of DSL services put an end to the unequal treatment of telephone operators and cable providers in the broadband access market.

What remains of the previously very generous unbundling requirements for competitors is essentially the obligation to unbundle the copper local loop in all areas in which the incumbent is using this access technology for narrowband telecommunications purposes. Competitive local exchange carriers are granted access to the copper local loop at TELRIC prices whenever they intend to (also) provide telecommunications services over this line. Since local circuit switching is no longer regulated, entrants are now required to build out their network to the local switch and set

19 FCC 05-150 available at http://hraunfoss.fcc.gov/edocs_public/attachmatch/FCC-05-150A1.pdf.

20 Following the 1996 Act, the FCC had introduced the term “information services” instead of “enhanced serviced”. Information services continued to be exempted from common carrier regulation. Internet Service Providers were explicitly excluded from the term "telecommunications carrier". In its 1998 Universal Service Report to Congress, the FCC had declared that "Internet Service Providers that lease telecommunications capacity from common carriers, in order to operate an Internet backbone, are not themselves common carriers, but are providers of information services.” (Oxman, 1999: 23) 
up own switching equipment or alternatively buy switching and transport services from other carriers. For competition in the broadband access market the new regulatory framework relies on infrastructure-platform competition from Cable-TV networks and high-speed wireless technologies. DSL service by competitors using the unbundled local loop is only a source of competition when the unbundled local loop is available and technically adequate to support broadband services or when local circumstances are such that obligations to provide access to a high-capacity loop apply. For the development of Next Generation Access networks (FTTH and FTTC projects) the regulatory framework practices restraint in order to entice investments by either the incumbent or new entrants.

\subsection{Assessment of telecommunications regulation in the U.S.}

The fundamental change in U.S. unbundling policy since 2003 is a direct reflection of the impact that network convergence has had on regulatory policy. U.S. courts believe that infrastructure platform competition has increased to such a significant extent, that asymmetric regulation of telecommunications infrastructure, especially for broadband access, is no longer justifiable. They plead for regulatory abstinence to further the investment incentives in broadband infrastructure.

The practical implications of the new limited unbundling rules have not yet been analyzed. This is mostly due to the fact that the transition periods, in which most of the discontinued unbundled elements were still on offer, lasted into the year 2006. The effects of the new unbundling rules on competition in the telecommunications markets are therefore only now becoming evident. At this time, the appraisal of the new unbundling regulation is therefore mostly theoretical.

Positive, is the fact that the current U.S. unbundling legislation strives to avoid overregulation by using a limiting theoretical framework for the identification of the regulatory basis. The Supreme Court decision of 1999 explicitly mentions the essential facilities doctrine used in antitrust law as an example of a standard which should be applied in telecommunications regulation in order to limit the scope of market intervention. Justice Breyer, for instance, suspected that Congress did not explicitly write the essential facilities principle into the 1996 Act because it had been uncertain of the extent of necessary unbundling. Nevertheless, the Supreme Court was certain that Congress had intended for a limiting principle analogue to the essential facilities doctrine (Hausman and Sidak, 2000: 436 and 445). 
A further positive aspect of the present U.S. framework is the particular focus it places on investment incentives and infrastructure-platform competition. There are less unbundled elements at regulated prices on offer. This will presumably take downward pressure off retail prices and may therefore foster investments. Bauer (2005: 80) argues that ILECs have accelerated their DSL rollout since the changes in the unbundling requirements.

New to the framework is also the focus on regional differences. Especially in a country with such diverse geographical and demographic regions as are present in the U.S., the flexibility to regulate according to local circumstances is mandatory. A further positive element of the regulatory regime is that the Telecommunications Act requires the FCC to review the regulation every two years and to forebear from regulating if the measures are no longer in the public interest (Stockdale. 2003: 263-264).

The critical aspects of the present U.S. telecommunications regulation mostly have in common that the actual provisions are not always in line with the theoretical framework described, for instance, in the Triennial Review Remand Order of 2005 (FCC, 2005). Rather, the provisions often seem to be guided by a political policy decision where to regulate and where not to intervene. For instance, narrowband local loop unbundling is regulated everywhere, even when facilities-based competition from cable operators, that also offer voice telecommunications services, is strong. On the other hand, fiber to the home (FTTH) or fiber to the curb (FTTC) projects are everywhere exempted from regulation, even when no alternative infrastructure-platform is present. In overbuild situations, the FCC only requires the telecommunications incumbent to offer a lowspeed 64 kbps channel on an unbundled basis. A low-speed channel will, however, not suffice to compete in the broadband market. When there is no alternative infrastructure platform, as is often the case in rural areas where cable access is not available and competition from wireless operators is stifled by institutional barriers, then the incumbent carrier will have a monopoly position in the broadband access market. To allow for effective competition also in these broadband access markets, access to the ducts and ductworks of the incumbent is necessary, together with an unbundling offer for the last segment of the end-user line from the customer premises to the street cabinet to which the fiber network is built out.

Lastly, the new regulatory framework of the U.S. has been criticized for not doing enough to further the goal of fostering infrastructure-platform competition. Speta (2004: 5) argues: "Congress ought to quickly adopt proposals that decrease the barriers to entry faced by wireless 
and cable operators.” He views especially the reform of spectrum policy as critical to increase intermodal competition in broadband access. The government could increase available spectrum; it could open spectrum use to any kind of service the owner of the spectrum would like to offer and state and municipal policy concerning the use of public right of way could be reformed (Speta, 2004:62). Others have argued for establishing a property rights system in spectrum and allowing spectrum to be traded so that spectrum can be allocated to its most efficient use (Faulhaber, 2006 and Hazlett and Munoz, 2004).

In conclusion, the U.S. legal framework, as laid down in the 1996 Act and interpreted by the Triennial Review Order of 2003 (FCC, 2003), in the Order on Reconsideration of 2004 (FCC, 2004) as well as in the Triennial Review Remand Order of 2005 (FCC, 2005) meets many of the demands the disaggregated regulatory framework places on regulation. However, the actual regulations being implemented are not always grounded in this theory. The U.S. regulation needs to consistently verify whether entry barriers hinder actual and potential competition in a market.

\section{The Regulatory Framework in the EU}

\subsection{History of Telecommunications Regulation in Europe ${ }^{21}$}

Traditionally, European Countries had state-owned monopolies for the provision of telecommunications services. As in the U.S. an underlying rationale was that telecommunications services were generally regarded to be natural monopolies. Public ownership was justified by the social objectives pursued by telecommunications regulation such as universal service provision.

As part of the European integration process, the European Commission encouraged a common policy for the communications industry. In a 1987 Green Paper on Telecommunications Services, the Commission introduced the concept of open network provision (ONP), which was to further the goal of establishing a common market for communications services (Knieps, 2000: S92). With ONP policy, equal access to national communications infrastructure was to be achieved.

The Commission commenced the liberalization process in 1990 by first declaring the exclusive rights of national telecommunications carriers in the markets for value-added network services to 
be in violation of the common market. When the Maastricht Treaty of 1993 provided the legal basis for further measures, the Commission began a consultative process on telecommunications liberalization. The EU directives that were issued until the 1998 liberalization of most telecommunications markets in the EU are subsumed under the term "1998 regulatory package”. This legislative package focused on the transition from monopoly provision of fixed-line telecommunications services to establishing a competitive market. In order to become effective, directives issued by the Commission need to be implemented into national law by the member states. Most EU member states fully liberalized telecommunications services and infrastructure provision on January 1, 1998.

The 1998 regulatory package focused competition by interconnection at non-discriminatory, reasonable and transparent conditions. The interconnection charges of providers of public telecommunications services with a dominant market position were to be regulated ex ante and were additionally obliged to be based on costs. ${ }^{22}$ The more invasive instrument of network element unbundling for access to the local loop, including line-sharing, was enacted by the Commission on January 2001. As an EU regulation, this enactment immediately became national law in all member states.

\subsection{The present regulatory framework in Europe}

Fast technological developments in the market as well as the trend towards the convergence of telecommunication, Internet and media services led to the adoption of a new EU regulatory framework for electronic communications in March 2002. The framework consists of five Directives, among these the Framework Directive ${ }^{23}$, the Access Directive ${ }^{24}$, and the Universal Service Directive ${ }^{25}$, and several accompanying documents. ${ }^{26}$ This framework was implemented into the national law of the member states by October 2003.

21 For an overview of telecommunications regulation in Europe see Knieps (2000) and Oldale and Padilla (2004).

22 At the time, the Commission suggested that market shares above the threshold of 25 percent are indicative of market power (Knieps, 2000: S94).

23 Directive (2002/21/EC available at: http://europa.eu.int/eur-lex/pri/en/oj/dat/2002/1_108/1_10820020424en00330050.pdf.

24 Directive 2002/19/EC available at:

25 http://europa.eu.int/eur-lex/pri/en/oj/d http://europa.eu.int/eur-lex/pri/en/oj/dat/2002/l_108/1_10820020424en00510077.pdf. 
The new regulatory framework pursues two main objectives. First, it wants to offer a consistent framework for different electronic communications platforms. Second, it wants to harmonize the regulation of electronic communications in the EU member states. To achieve its first objective, the framework of 2002 is neutral towards the technology employed for the provision of electronic communications. The European answer to network convergence therefore was not, as in the U.S. to curtail sector-specific regulation, but rather to extend regulation to further communication technologies such as Internet, cable and satellite. To harmonize regulatory measures in the member states, the framework draws from the common principles and methodology of competition law. The close accord with competition policy also serves to emphasize the transitory character of regulation and facilitates the transition into general competition law once sector-specific regulation is deemed unnecessary.

\section{List of recommended markets}

Probably the most influential of the accompanying documents to the framework directives is the Recommendation on relevant markets ${ }^{27}$. In this document, the EU has defined a set of product and service markets which may warrant sector-specific ex-ante regulation. The criteria used by the Commission to identify markets which may not tend to effective competition without regulation are subsumed in a so-called "three criteria test":

"The first criterion is the presence of high and non-transitory entry barriers whether of structural, legal or regulatory nature. ...the second criterion admits only those markets the structure of which does not tend towards effective competition within the relevant time horizon. ...The third criterion is that application of competition law alone would not adequately address the market failures concerned.” (C(2003)497: §9).

The list of recommended markets is continuously reviewed by the Commission. All of the three criteria must be fulfilled for a market to be added to the list of relevant markets to be analyzed by national regulatory authorities (NRAs). If one of the criteria fails, then a market will be taken off the list (C(2003)497: §16). Legally, the list is not a binding part of the framework. However, it is expected that all NRAs analyze the pre-defined markets.

\footnotetext{
26 The two other directives are the Authorisation Directive and the Data protection Directive.

27 C(2003)497 available at: http://ec.europa.eu/information_society/topics/telecoms/regulatory/maindocs/documents/recomen.pdf
} 
Currently the Commission's list includes 18 markets. ${ }^{28}$ Seven of these are on the retail level, as for instance telephone access for residential customers, the provision of local calls and the provision of international calls. The remaining eleven markets are on the wholesale level, as for instance unbundled access to the local loop, call origination and call termination. The recommendation does not include Internet retail markets or Internet interconnectivity services. The wholesale product markets which are relevant to Internet service provision are: "call origination on the public telephone network provided at a fixed location" (market 8 on the list); "wholesale unbundled access (including shared access) to metallic loops and subloops for the purpose of providing broadband and voice services” (market 11); “wholesale broadband access” (market 12); and “wholesale terminating segments of leased lines” (market 13).

\section{Significant Market Power (SMP)}

The list of recommended markets serves as a starting point for market analyses of the NRAs. Using the principles and methodology of general competition law the NRAs are to analyze the markets suggested by the EC (and any additional markets added by the NRA which pass the threecriteria test). The confirmation of the existence of the relevant market in the national context is not yet considered sufficient for the identification of market power. The NRAs are subsequently obliged to analyze the market power of the players in the defined market. The localization of Significant Market Power (SMP) is considered the ultimate criterion which needs to be determined for the imposition of ex-ante regulatory measures.

The definition of SMP is therefore of central importance for the specification of the regulatory basis. The Framework directive of 2002 defines SMP as "a position of economic strength affording an undertaking the power to behave to an appreciable extent independently of competitors, customers and ultimately consumers."29 This definition corresponds to the definition of market dominance used in EU general competition law. The alignment of these definitions was one main aim of the new regulatory framework with the intent of making the decisions taken by National Regulatory Authorities compatible with European competition law.

To assess SMP the NRAs are to consider "the power of the undertaking concerned to raise prices by restricting output without incurring a significant loss of sales or revenues” (EC, 2002: §73). The

28 The Appendix includes the complete Annex of the Commission Recommendation which lists the markets recommended for analysis. 
Commission recognizes that the market power of a firm can be constrained by actual as well as by potential competitors (EC, 2002: §74). On the other hand, the Commission emphasizes the criterion of market shares to establish whether a firm has SMP (EC, 2002: §75). Market shares below 40 percent of sales value (or sales volume) are considered to be uncritical, while a market share which exceeds 50 percent of sales value is considered sufficient evidence of significant market power. ${ }^{30}$ The Commission further advises NRAs to consider the development of the market shares over time and to interpret stable market shares as evidence of dominance and fluctuating market shares as evidence of a lack of market power. Further criteria that NRAs are to consider when assessing SMP include, among others, "control of infrastructure not easily duplicated”, “economies of scale”, “economies of scope”, and “vertical integration” (EC, 2002: §78).

The SMP criteria of the Commission are open to much wider interpretation of market power than the criteria extended by the essential facilities doctrine applied in U.S. antitrust law and increasingly also in European competition law (Knieps, 2006: 54). The criterion "control of infrastructure not easily duplicated” is not equivalent to the definition of an essential facility. First, it is not clear how "not easily" is to be interpreted. Second, economies of scale and scope are common in network industries. They do not automatically substantiate a natural monopoly. A proper limiting standard would require economies of scale and scope to substantiate a natural monopoly. Furthermore, even a natural monopoly could still be disciplined by potential competition, which in theory is a factor the Commission lists for determining $\mathrm{SMP}^{31}$. To exclude the threat of potential competition the criterion of sunk costs would be important. The FCC includes sunk costs in its list of structural entry barriers (see section 2.2 above).

29 EC, 2002: §5.

30 SMP is defined differently from the concept of market dominance, which was used in the previous regulatory framework of 1998. A firm used to be designated as having market power which justifies ex-ante regulation when its percentage share of sales volume exceeded 25 percent.

31 See reference to Knieps (1997 and 2006) in Footnote 17 above. 


\section{Regulatory remedies}

Once an NRA has defined a relevant market and assessed SMP the NRA is obliged to impose appropriate regulatory remedies as suggested in the Access Directive (for wholesale markets) and Universal Service Directive (for retail markets). While the NRAs can independently choose and implement their regulatory remedies, they must be justified in relation to the objectives of the regulatory framework and must be proportionate to the problem to be solved (EC; 2002: §117). When SMP is not found, any existing regulations are to be removed.

\section{Article 7 procedures}

Article 7 of the Framework Directive extends supervisory powers to the European Commission with regard to the notifications made by the NRAs. Within a one-month period the Commission can either approve of a notification or issue a veto. The veto power applies to the market definition of an NRA as well as to the SMP analysis. A veto right does not exist for the remedies proposed by an NRA. Should the Commission require more time for an in-depth investigation into the NRA analysis, it can append two months of further investigation.

\subsection{The regulation of Internet relevant markets}

For the Internet relevant markets on the list of recommended markets the experience shows that the NRAs have tended to confirm the speculation of the Commission that these markets should be regulated and have applied most of the remedies proposed. For instance, market 8, which encompasses call-origination, including the dial-up connection to Service Platforms of independent ISPs, has been notified by 21 European countries. All found the incumbent operator to have SMP, based mainly on high market shares and control over not easily duplicated infrastructure. Most of the notifying countries imposed the whole catalogue of possible remedies suggested by the Commission (from transparency, non-discrimination, accounting separation to access, price-control and cost orientation) (Kiesewetter, 2006: 31).

For market 11, which encompasses the unbundled local loop and sub-loops, of the 20 countries that have notified this market, all find the incumbent operator to have SMP (based again on market shares and barriers to entry into the market). Almost all of the notifying NRAs impose the entire catalogue of possible remedies; all of the NRAs require the access rates to be costs oriented (Kiesewetter, 2006: 42). 
18 countries have notified market 12, wholesale broadband access, including bitstream access. All notifying countries find at least the incumbent carrier to have SMP based on high market shares and control over not easily duplicated facilities. 13 of the 18 countries impose the entire spectrum of possible remedies on the incumbent (Kiesewetter, 2006: 46).

Market 13, which encompasses terminating segments of leased lines, thus lines which typically connect the local exchange and customer premises (Cave et al., 2006: 79), has been notified by 17 countries. Again all countries find the incumbent to have SMP based on high market shares and barriers to entry into the market. Most of the NRAs, however, impose less remedies than on the above discussed markets. Most have in common that access must be granted on transparent and non-discriminatory terms (Kiesewetter, 2006: 50).

\subsection{Current Developments}

The 2002 regulatory framework is currently under review. The Commission held public consultations in December 2005 and January 2006. From these consultations the Commission has identified two areas needing fundamental reform and some areas in which minor changes can improve the framework (see EC, 2006). The first area for fundamental reform is spectrum management. Perhaps most important, the Commission wants to strengthen the rights of service providers by giving them the freedom to use any technology of their choosing in combination with the spectrum and the freedom to offer any services of their choosing on the spectrum. The second area identified for fundamental reform is the procedure for the review of relevant markets. The commission plans to simplify the market analysis and notification requirements for those markets that were found to be competitive in a previous analysis or whenever the notification features only small changes compared to the previous notification. Among the other proposed changes is the Commission's intent to extend its veto powers to include also the remedies proposed by NRAs. Furthermore, in the present framework Article 5 of the Access Directive allows NRAs to place access and interconnection obligations also on non-SMP operators whenever they control the access to an end-user ( $\S 1 \mathrm{~b})$. The Commission plans to qualify this right by allowing such obligations only after prior authorization by the Commission.

The Commission proposes to reduce the list of relevant markets recommended for ex-ante regulation to ten to twelve markets by deleting a number of retail markets from the list. This new list could come into effect in 2007 and apply for about 2-3 years. The Internet related wholesale 
markets (currently markets 8, 11, 12 and 13) would remain on the list. The reform process is continued by negotiation in and between the Parliament and the Council in the first quarter of 2007. This step may take up to two years, until early 2009. The revised framework would then become effective in 2010 .

\section{The regulation of NGNs}

The Commission's Guidelines on the new regulatory framework state that emerging markets "should not be subject to inappropriate ex-ante regulation. This is because premature imposition of ex-ante regulation may unduly influence the competitive conditions taking shape within a new and emerging market. At the same time, foreclosure of such emerging markets by the leading undertaking should be prevented (EC, 2002: §32).” This vague instruction leaves much room for interpretation by the member states. Are next generation networks (NGNs) new and emerging markets? How is foreclosure to be prevented when the application of regulation to new markets is viewed so skeptically?

The European Regulators Group (ERG) published a draft consultation on regulatory principles for Next Generation Access (NGA) in May 2007. In this document, it states that "the inclusion of the fibre loop into market 11 is compatible with the definition of the Access Directive, but would require a change of the Recommendation to include fibre into the relevant market...Market 12 does not require a change of the Recommendation as, by definition, it already comprises all kinds of wholesale broadband access products that can be delivered higher in the network" (ERG, 2007: VII). The ERG therefore does not view NGA as a new market. The group discusses as possible remedies: "Unbundling the shortened local loop ending at the street cabinet implies the need for colocation at the street cabinet and backhaul service from the cabinet to the operator's node.” (ERG, 2007:8). ${ }^{32}$

32 The German national regulator, the Bundesnetzagentur (BNetzA) published a draft consultation in April 2007 for its market definition and market analysis for Market 11 and Market 12. The BNetzA comes to the same conclusion as the ERG. See http://www.bundesnetzagentur.de/enid/84a95ca7a209586a04d3e309b0d8b5e0,0/ Press_Section/Press_Releases_/_Newsletter_10d.html\#Expansion_of_fiberoptic_access_networks. 


\subsection{Assessment of telecommunications regulation in Europe}

The overview of telecommunications regulation in the U.S. showed that convergence there had the effect of curtailing regulations in the telecommunications sector. In Europe network convergence has had an opposing effect. Here convergence was answered by extending the scope of the regulatory framework to other platforms for electronic communication.

The experience with the new regulatory framework is relatively short, considering that many countries have taken several years to complete the market analysis of the markets on the Commission list of recommended markets. The implementation of remedies took a long time and the effect of these remedies is often only now becoming apparent. Therefore, much as with the assessment of the current U.S. regulatory framework, the assessment of the European Framework remains theoretical in many points.

Positive, is the fact that the framework is in many respects based on economic criteria. The Commission, for instance, recognizes the importance of potential competition (EC, 2002: §74), and also the control of monopolistic bottlenecks (EC, 2002: §78) as criteria to establish whether a firm has the power to act independently of competitors and customers in a market. The framework is forward-looking in that it focuses on incentives for innovation and investment (Art. 8 (2c) of the Framework directive), and it includes a mechanism for eliminating regulatory obligations once made obsolete by market developments. A regular review process guarantees that market changes and technological developments can influence the assessment of SMP in a market and lead to the withdrawal of regulatory burdens.

Also positive are the proposed changes in spectrum management as they address some of the most pressing issues, also being discussed in the U.S., important for strengthening infrastructureplatform competition in the market for broadband access (EC, 2006: 11-15). Wireless access technologies could become especially important in European countries such as Italy, Spain and Greece $^{33}$, in which the cable network is not widely deployed and where infrastructure-platform competition in broadband access would be strengthened significantly by a wireless access product.

33 See OECD Communications Outlook (2005: 219, Table 7.3.) 
The most important drawback of the European regulatory framework is its tendency to overregulation. Blankart et al. (2007: 11) find that the three-criteria test underlying the regulatory framework is, in essence, in accordance with the bottleneck theory and could successfully be used to limit regulation to instances in which monopolistic bottlenecks hinder competitive market outcomes $^{34}$. The "presence of high and non-transitory entry barriers" (first criterion) in economic terms could be rewritten as a market with natural monopoly characteristics requiring sunk investments. Such a monopoly can be considered to pass criterion two, which requires the market to not tend towards effective competition within the relevant time horizon. In current practice, however, the three criteria test is not being applied in this economically sound manner. The Commission instead has added markets to the list of relevant markets which cannot be considered natural monopolies (this holds especially true for all of the retail markets on the list). Oldale and Padilla (2004: 52) speculate that the list of relevant wholesale markets is artificially inflated in order to facilitate short-term successes in market performance by increasing the number of firms active in the retail markets. They criticize the fact that the framework relies on competition law instruments for market analysis, but does not use the "limiting principles embedded in the competition law rules [...] when specifying the remedies to be used.”

Besides the fact that the three-criteria test is not used to limit regulatory intervention to instances in which network-specific market power can be identified, the framework introduces a second step in which SMP status needs to be determined for the imposition of regulatory remedies. Since the theoretical determinants of SMP also include criteria such as the control over infrastructure not easily duplicated and the absence of active and potential competition, the framework could still provide for limiting principles in accordance with the disaggregated regulatory approach. However, the additional SMP criteria employed by the commission, such as the focus on market shares, tend to water down market power identification rather than have a limiting effect on when SMP is identified. The notifications of the NRAs so far show that even when more determinants of market power are theoretically laid down, in their practical implementation of the framework directive and especially in their determination of SMP, the focus of the NRAs is again very much on market shares. Even if the threshold for assuming market power has moved from 25 percent market share to 50 percent, there is a danger that the value attached to the other criteria mentioned by the Commission pales in comparison to the easily grasped market share figures. While 50 percent may be correlated with dominance in many sectors of the economy, network sectors often

34 See reference to Knieps (1997 and 2006) in footnote 17 above. 
have large market players due to the relevance of economies of scale and scope in these markets. Market share alone therefore does not suffice to determine market power in a network sector.

Consider the Internet related markets on the Commissions' list of relevant markets. It was shown above that all European countries that have notified these markets have found at least one operator to have SMP and imposed most of the possible remedies suggested by the Commission (Kiesewetter, 2007). The finding of SMP was always also substantiated by high market shares of the incumbent carrier. With a more limiting approach to intervention by market power regulation it is, however, most questionable if the regulation of markets 8 and 12, which respectively provide for dial-up Internet access and bitstream wholesale access are necessary once market 11 is effectively regulated, by which access to the unbundled local loop is guaranteed. An economic justification for unbundled access to the local loop is only given whenever no competing access services from cable or wireless carriers are available or are likely to become available should the incumbent make above competitive profits in the market. Competition by new entrants renting the local loop in order to provide alternative broadband access services suffices to hinder the incumbent from abusing its market power in the access market. It has been demonstrated by entrants into many local markets that the additional services provided by wholesale bitstream access, such as access to the DSLAM and backhaul transportation of traffic can be competitively supplied.

The framework leads to a broader regulatory basis than economically justified. This is demonstrated by the fact that the Commission explicitly finds that a network owner, that is not found to have power over essential facilities, can nevertheless be found to have a dominant position in the market for that access facility. According to the Commission there is a difference in determining SMP for the purposes of ex-ante market intervention and finding that an undertaking is the owner of an "essential facility" in the context of general competition law. While the owner of an essential facility also has SMP on the market for this facility, the Commission finds that the converse is not necessarily true: “the fact that a given facility is not 'essential' or 'indispensable' for an economic activity on some distinct market, within the meaning of the existing case law does not mean that the owner of this facility might not be in a dominant position” (EC, 2002: §81). The regulatory framework therefore explicitly calls for regulation even in cases in which a network element cannot be defined as "essential” using the criteria of the essential facilities doctrine. 


\section{Conclusions}

The overview given in this paper focused on the regulation of access to network elements of the local telecommunications infrastructure. It was shown that the trend to the convergence of telecommunications, media and Internet services has had a different impact on traditional telecommunications regulations in the U.S. and the EU.

In the U.S., liberalization of local telecommunications services was introduced in 1996 and was at first accelerated by intensive unbundling regulations. When infrastructure-platform competition increased these regulations were subsequently curtailed dramatically. Today incumbents are only obliged to offer unbundled access to the local loop for narrowband voice telecommunications services. For broadband access U.S. regulation currently relies on competition by other infrastructure platforms.

In Europe full liberalization of telecommunications services provision was introduced in 1998. Convergence was accounted for in the new EU regulatory framework for electronic communications of March 2002 which equally applies to different electronic communications platforms. In Europe the advent of network convergence has not had the effect of reducing regulation of wholesale telecommunications inputs. Rather, market power regulation was extended to sectors previously not included.

The analysis concludes that U.S. deregulation has gone too far with respect to some broadband access markets. The importance of competitive broadband access is increasing with the advent of NGN services. If in some geographic markets no infrastructure-platform competition exists or is likely to develop, then the FCC should use the Telecommunications Act of 1996 to regulate access to monopolistic network elements.

The assessment of the European regulation of telecommunications services concludes that the possibilities which the framework provides for limiting current overregulation are not being used. A consistent application of the three criteria test and a commitment to limit regulation only to market areas in which network specific market power, due to ownership of monopolistic bottlenecks, is identified, would result in regulating only those remaining access markets in which infrastructure-platform competition has not yet evolved and is not likely to evolve under prevailing market conditions. The list of relevant markets could be reduced dramatically. All service markets 
and all wholesale markets which concern services on higher network levels, such as the provision of telephone access and telephone calls, should be removed from the list. 


\section{Appendix}

Annex of the "COMMISSION RECOMMENDATION of 11 February 2003 on relevant product and service markets within the electronic communications sector susceptible to ex ante regulation in accordance with Directive 2002/21/EC of the European Parliament and of the Council on a common regulatory framework for electronic communication networks and services"

(notified under document number C(2003) 497)

\section{Retail level}

1. Access to the public telephone network at a fixed location for residential customers.

2. Access to the public telephone network at a fixed location for non-residential customers.

3. Publicly available local and/or national telephone services provided at a fixed location for residential customers.

4. Publicly available international telephone services provided at a fixed location for residential customers.

5. Publicly available local and/or national telephone services provided at a fixed location for nonresidential customers.

6. Publicly available international telephone services provided at a fixed location for non-residential customers.

These six markets are identified for the purpose of analysis in respect of Article 17 of the Universal Service Directive.

Together, markets 1 through 6 correspond to 'the provision of connection to and use of the public telephone network at fixed locations', referred to in Annex I(1) of the Framework Directive. This combined market is also referred to in Article 19 of the Universal Service Directive (for possible imposition of carrier call-bycall selection or carrier selection).

7. The minimum set of leased lines (which comprises the specified types of leased lines up to and including 2Mb/sec as referenced in Article 18 and Annex VII of the Universal Service Directive).

This market is referred to in Annex I(1) of the Framework Directive in respect of Article 16 of the Universal Service Directive (the provision of leased lines to end users).

A market analysis must be undertaken for the purposes of Article 18 of the Universal Service Directive which covers regulatory controls on the provision of the minimum set of leased lines. 


\section{Wholesale level}

8. Call origination on the public telephone network provided at a fixed location. For the purposes of this Recommendation, call origination is taken to include local call conveyance and delineated in such a way as to be consistent with the delineated boundaries for the markets for call transit and for call termination on the public telephone network provided at a fixed location.

This market corresponds to that referred to in Annex I(2) of the Framework Directive in respect of Directive 97/33/EC (call origination in the fixed public telephone network).

9. Call termination on individual public telephone networks provided at a fixed location.

For the purposes of this Recommendation, call termination is taken to include local call conveyance and delineated in such a way as to be consistent with the delineated boundaries for the markets for call origination and for call transit on the public telephone network provided at a fixed location.

This market corresponds to the one referred to in Annex I(2) of the Framework Directive in respect of Directive 97/33/EC (call termination in the fixed public telephone network).

10. Transit services in the fixed public telephone network.

For the purposes of this Recommendation, transit services are taken as being delineated in such a way as to be consistent with the delineated boundaries for the markets for call origination and for call termination on the public telephone network provided at a fixed location.

This market corresponds to the one referred to in Annex I(2) of the Framework Directive in respect of Directive 97/33/EC (transit services in the fixed public telephone network).

11. Wholesale unbundled access (including shared access) to metallic loops and sub-loops for the purpose of providing broadband and voice services.

This market corresponds to that referred to in Annex I(2) of the Framework Directive inrespect of Directive 97/33/EC and Directive 98/10/EC (access to the fixed public telephone network, including unbundled access to the local loop) and to that referred to in Annex I (3) of the Framework Directive in respect of Regulation No 2887/2000.

12. Wholesale broadband access.

This market covers 'bit-stream' access that permit the transmission of broadband data in both directions and other wholesale access provided over other infrastructures, if and when they offer facilities equivalent to bit-stream access. It includes 'Network access and special network access' referred to in Annex I(2) of the Framework Directive, but does not cover the market in point 11 above, nor the market in point 18 .

13. Wholesale terminating segments of leased lines.

14. Wholesale trunk segments of leased lines.

Together, the wholesale markets 13 and 14 correspond to those referred to in Annex I(2) of the Framework Directive in respect of Directive 97/33/EC and Directive 98/10/EC (leased line interconnection) and to those referred to in Annex I(2) of the Framework Directive in respect of Directive 92/44/EEC (wholesale provision of leased line capacity to other suppliers of electronic communications networks or services). 
15. Access and call origination on public mobile telephone networks, referred to (separately) in Annex I(2) of the Framework Directive in respect of Directives 97/33/EC and 98/10/EC.

16. Voice call termination on individual mobile networks.

This market corresponds to the one referred to in Annex I(2) of the Framework Directive in respect of Directive 97/33/EC (call termination on public mobile telephone networks).

17. The wholesale national market for international roaming on public mobile networks.

This market corresponds to the one referred to in Annex I(4) of the Framework Directive.

18. Broadcasting transmission services, to deliver broadcast content to end users.

Note

National regulatory authorities have discretion with respect to the analysis of the market for 'Conditional access systems to digital television and radio services broadcast' in accordance with Article 6(3) of the Access Directive. Article 6(3) of the Access Directive provides that Member States may permit their NRAs to review the market for conditional access system to digital television and radio services broadcast, irrespective of the means of transmission. 


\section{References}

Bauer, J. (2005), Unbundling Policy in the United States Players, Outcomes and Effects, Communications \& Strategies, 57, 59-82.

Berg et al. (2006), Abschlussbericht der Projektgruppe "Rahmenbedingungen der Zusammenschaltung IP-basierter Netze“, available at: http://www.bundesnetzagentur.de/media/archive/8287.pdf.

Blankart, Ch.B., G. Knieps and P. Zenhäusern (2007), Regulation of New Markets in Telecommunications? - Market dynamics and shrinking monopolistic bottlenecks, forthcoming in European Organization Business Review.

Cave, M., U. Stumpf and T. Valletti (2006), A review of certain markets included in the Commission's recommendation on relevant markets subject to ex ante regulation, Independent report to the European Commission.

European Commission (2002), Commission Guidelines on market analysis and the assessment of significant market power under the Community regulatory framework for electronic communications networks and services, Official Journal of the European Communities, 2002/C 165/03, Brussels.

European Commission (2006), Communication from the Commission to the Council, the European Parliament, the European Economic and Social Committee and the Committee of the Regions on the Review of the EU Regulatory Framework for electronic communications networks and services, Commission Staff Working Document, COM(2006) 334 final, Brussels.

European Regulators Group (2007), ERG Consultation Document on Regulatory Principles of NGA (ERG (07) 16, available at:

http://www.erg.eu.int/doc/publications/consult_regprinc_nga/erg_cons_doc_on_reg_princ_ of_nga.pdf.

Faulhaber, G. (2006), The future of wireless telecommunications: Spectrum as a critical resource, 
Information Economics and Policy 18, 256-271.

FCC (1996), In the Matter of Implementation of the Local Competition Provisions in the Telecommunications Act of 1996; Interconnection between Local Exchange Carriers and Commercial Mobile Radio Service Providers, CC Docket Nos. 96-98, 95-185, First Report and Order, 11 FCC Rcd 15499, 15616-775 (Local Competition Order).

FCC (2003), In the Matter of Review of the Section 251 Unbundling Obligations of Incumbent Local Exchange Carriers; Implementation of the Local Competition Provisions of the Telecommunications Act of 1996; Deployment of Wireline Services Offering Advanced Telecommunications Capability, CC Dockets Nos. 01-338, 96-98, 98-14, Report and Order and Order on Remand and Further Notice of Proposed Rulemaking, Federal Communications Commission, (Triennial Review Order).

FCC (2004), In the Matter of Review of the Section 251 Unbundling Obligations of Incumbent Local Exchange Carriers, Order on Reconsideration, CC Docket No. 01-338.

FCC (2005), In the Matter of Unbundled Access to Network Elements; Review of the Section 251 Unbundling Obligations of Incumbent Local Exchange Carriers, WC Docket No. 04-313 and CC Docket No. 01-338 (Triennial Review Remand Order).

Hausman J. and J. G. Sidak, (2000), A Consumer-Welfare Approach to the Mandatory Unbundling of Telecommunications Networks, Yale Law Journal 109, 417-505.

Hausman, J. and J. G. Sidak (2005), Did Mandatory Unbundling Achieve its Purpose? Empirical Evidence from Five Countries, Journal of Competition Law and Economics, 1, 173-245.

Hazlett, T. and R. Muñoz (2004), What Really Matters in Spectrum Allocation Design, Working Paper 04-16, AEI-Brookings Joint Center for Regulatory Studies.

Kiesewetter, W. (2007), Marktanalyse und Abhilfemaßnahmen nach dem EURegulierungsrahmen im Ländervergleich, WIK Diskussionsbeiträge, 288, Bad Honnef.

Knieps, G. (1985), Entstaatlichung im Telekommunikationsbereich: Eine theoretische und 
empirische Analyse der technologischen, ökonomischen und institutionellen Einflußfaktoren, Tübingen.

Knieps, G. (1997), Phasing out Sector-Specific Regulation in Competitive Telecommunications, Kyklos 50, 325-339.

Knieps, G. (2000), Interconnection and Network Access, Fordham International Law Journal, 23, S90 - S115.

Knieps, G. (2006), Sector-specific market power regulation versus general competition law: Criteria for judging competitive versus regulated markets, in: Sioshansi F.P. and W. Pfaffenberger, (Eds.), Electricity Market Reform: An International Perspective, Amsterdam.

Marcus, J.S. (2002), The Potential Relevance to the United States of the European Union's Newly Adopted Regulatory Framework for Telecommunications, OPP Working Paper Series 36, FCC, Washington D.C.

Nuechterlein, J.E. and P.J. Weiser (2005), Digital Crossroads: American Telecommunications Policy in the Internet Age, Cambridge.

Oldale, A. and J. Padilla (2004), From state monopoly to the "investment ladder": competition policy and the NRF, in: The Pros and Cons of Antitrust in Deregulated Markets, Konkurrensverket, Swedish Competition Authority, 51-77.

Oxman, J. (1999), The FCC and the Unregulation of the Internet, OPP Working Paper Series 31, FCC, Washington D.C.

Speta, J. (2000), Handicapping the Race for the Last Mile?: A Critique of Open Access Rules for Broadband Platforms, Yale Journal on Regulation, 17, 39-91.

Speta, J. (2004), Deregulating Telecommunications in Internet Time, Washington and Lee Law Review, 1063 - 1154. 
Stockdale, D.K. (2003), The Regulation, Deregulation, and Nonregulation of Telecommunications and the Internet in the United States, in: Barfield, C., G. Heiduk and P.J.J. Welfens (Eds.), Internet, Economic Growth and Globalization, Berlin.

Vogelsang (2005), Interview conducted by Karl-Heinz Neumann, Communications and Strategies, 57, 109-115. 